\title{
Environmental Perceptions of Primary School Fourth Grade Students
}

\author{
Ramazan Peker (Corresponding author) \\ Nusretiye Primary School, Ministry of National Education \\ Nusretiye Quarter, Kartepe, Kocaeli, 41320, Turkey \\ Tel: 90-262-353-2242Ｅ-mail: rzpeker@gmail.com
}

\begin{abstract}
Salih Ceylan
Faculty of Education, Burdur Mehmet Akif Ersoy University

İstiklal Yerleşkesi, Burdur, 15100, Turkey

Tel: 90-248-213-4000 E-mail: sceylan@mehmetakif.edu.tr
\end{abstract}

Received: June 1, 2020 Accepted: June 27, 2020 Published: June 30, 2020

doi:10.5296/jei.v6i1.17153ＵRL: https://doi.org/10.5296/jei.v6il.17153

This study is part of Ramazan Peker's Doctoral Dissertion titled "The Evaluation of Environmental Perceptions of Primary School Fourth Grade Students and Their Attitudes and Behaviors Towards the Environment", in which accepted at Burdur Mehmet Akif Ersoy University Institute of Educational Sciences.

\begin{abstract}
This study aims to identify environmental perceptions of primary school fourth grade students. The population of this study, which is designed as a descriptive survey model, consists of 97 male and 142 female 239 fourth grade students who are attending public primary schools in Kocaeli Province in the second term of 2018-2019 academic year. Data of research were evaluated by content analysis and descriptive analysis methods. Inter-rater reliability was evaluated by inter-rater reliability formula and Cohen's Kappa Coefficient. According to the findings of the research, inter-rater reliability was high and acceptable in both statistics. Fourth grade students created 45 different and acceptable metaphors about the environment. These metaphors were analyzed in terms of their common features and were collected under 5 different conceptual categories. It was revealed that fourth grade students
\end{abstract}


mostly referred to the environment with the metaphors of 'Life', 'Home', 'Paradise', and that students' perceptions of the environment are related to a good world. The majority of students perceived the concept of 'Environment' as 'Environment as Expression of Vitality'. As a result of research, in the process of teaching environmental issues, it can be said that emphasizing that 'Environment as a Liveliness Expression', factor of environment supporting the vitality can increase the rate of educational access on environmental issues.

Keywords: Environmental education, Perception of environment, Primary school, Primary school students

\section{Introduction}

Environment is defined as the integrity of processes, energies and materials that ensure and influence the life of a living creature or the society of living creatures (Kocatas, 2014), the ecosystem of a certain region at the local national or global level (Hook, 2016), the environment and the space of living creatures (Turkmen, 2005; Basal, 2015; Sever \& Yalcinkaya, 2018), the place where the basic vital needs of a living creature met (Miser, 2019) and generally a very wide concept including everything that affects an organism throughout its life (Chauan, 2008). Considering this wide concept, how children perceive the environment becomes quite important. Perception is defined as the first stage of cognitive communication with the world around the individual (Efron, 1969), the information received related to the abstract/concrete objects of the outside world (Inceoglu, 2011) and the process of detecting and interpreting stimuli from the outside environment (Woolfolk Hoy, 2004).

Perception shows the feature of being the first element of consciousness, and the representative images created by the outside world, that is perceptions, are effective in the actions of the individual. In the process of perception, the individual is informed from the outside world through the sense of feeling with five sensory organs consisting of physiologically tasting, seeing, smelling, touching and hearing. The perception of objects begins with individuals' establishing (concrete/abstract) relationships with objects in the outside world, making judgments about them and displaying certain behaviors about them (Inceoglu, 2011). When the individual is confronted with the situation and stimuli around him, he makes sense of these stimuli based on his previous experiences and interprets them accordingly (Woolfolk Hoy, 2004; Pickens, 2005; Akman \& Erden, 2012; Senemoglu, 2012). Because the individual's assessment of the attitude object in his mind does not exist alone, an attitude object can be related to other attitude objects and individuals can express their attitudes by making different evaluations in different situations (Sakallı Ugurlu, 2018).

Because the attitude of the individual affects his perceptions about the attitude object in the current situation and thus defining the situation. The definition of objects largely depends on the information structures, values and expectations of the individual (Fazio, 1989). When sensations arereceived, the mind immediately starts working on some of them. Thus; the sensory image that is conscious differs from what the organs perceive as seeing, hearing or feeling in reality (Slavin, 2013), what individual interprets and perceives can be substantially different from the reality (Pickens, 2005). Therefore, making generalizations from the perception of objects and events transformed into expressions, in other words, creating 
definition categories, is actualized by phenomenography, that is, metaphors (Demirkaya \& Tomal, 2008).

It is called a metaphor to provide examples similar to a situation or event in order to make things easily understandable. Metaphor; is the art of expressing an issue in a different way to facilitate the comprehensibility of expressions (Keklik, 1990). Lakoff and Johnson (2003) defined metaphor as the nature of cognition, including its systematic use that enables reasoning from one conceptual area to another conceptual area (cited in Lafferty \& Goldsmith, 2007). Morgan (1980), on the other hand, defined the metaphor as the tool we use when we try to comprehend an element of experience in terms of another element of experience. According to him, metaphors have a formative effect on our way of thinking, our language and science, as well as how we express ourselves in daily life. Yob (1992) defined the functional point in the understanding of metaphors as how it is understood but not what is understood. When a chart is successfully transferred to the new chart, it brings a different perspective to the previously unknown. Thus, what matters here is the cognitive gain of metaphors. Metaphors reflect and shape attitudes and eventually determine behaviors (Strenski, 1989).

According to Piaget (1920), children are not a miniature of adults in their cognitive activities, on the contrary they think qualitatively unique and differently (Vander Zanden, 1980). Therefore, children's environmental perceptions should be evaluated; training activities, which are defined as permanent desired behavior change processes, should be planned accordingly. Therefore, the aim of the study is to determine the metaphorical perceptions of fourth year primary school students regarding the concept of environment. Depending on this aim, 'which metaphors fourth year primary school students uses explaining their perceptions about the concept of 'environment'?' constitutes the question of the study.

\section{Method}

\subsection{Research Model}

This study was designed as a descriptive survey model to examine the perceptions of elementary school fourth year students about the concept of 'Environment'. Screening models are research approaches that aim to describe a situation that existed in the past or still exists as it is (Karasar, 2008), to collect data to determine certain characteristics of a group (Buyukozturk, Kilic Cakmak, Akgun, Karadeniz, \& Demirel, 2018).

\subsection{Study Group}

The study group of the research consisted of 329 fourth year students studying in Kocaeli, Izmit, Başiskele, Dilovası, Kandira and Kartepe districts. Since the metaphor is incompatible in terms of the source-subject and the relationship between the two, the expressions of 90 of these students were eliminated and the expressions of 239 were evaluated. In the final situation, 78 students were studying in Izmit District, 66 in Başiskele District, 54 in Dilovas District, 21 in Kandira District and 20 in Kartepe District. 97 of the participants were male, 142 were females. 


\subsection{Data Collection}

Interviews were conducted to determine perceptions of students regarding the environment. Interview form included a semi-structured data collection statement as 'Environment is like ... because ...' which is requested from the student to fill. With the semi-structured questionnaire, it was aimed to reveal the metaphors students have about the concept of 'environment'. How students answer this statement is exemplified by an independent topic. The students who stated that they could not understand or did not want to answer were asked to leave the question blank. The study was carried out during one course hour, accompanied by class teachers.

\subsection{Data Analysis}

The data obtained as a result of the application were evaluated firstly with descriptive analysis and then with content analysis. In content analysis, similar concepts are brought together under certain themes and interpreted (Yıldırım \& Şimşek, 2011). Analyzing and interpreting the metaphor data obtained from students were conducted in five stages, namely the classification (elimination and purification) stage, the category development stage, the validation and reliability stage, and the transfer of data to the computer environment (Dogru \& Sarac, 2013; Denis Celiker and Akar, 2015). In the category development stage, three key criteria were taken into account as; forming the individual definition categories in which Marton and Booth (1997) explained each case in a certain way, the fact that the categories have a logical relationship with each other, creating as few definition categories as possible in order to express critical variables related to the event and the phenomenon (as cited in Demirkaya \& Tomal, 2008).

Coder reliability was performed to verify the thematic coding of the researcher and to determine the level of reliability. Reliability coding control among raters not only helps descriptive clarity, but also provides good reliability control (Miles \& Huberman, 1994). Because the analyst triangulation, that is, comparing the findings obtained by independently analyzing the same qualitative data of two or more multiple raters, directly provides the opportunity to ensure consistency of the findings (Patton, 2014; translator, Celik \& Karatas, 2014). According to this; field expert social studies teacher was asked to re-code the conceptual category and the emerging metaphors. The coding obtained from this re-coding was compared with the coding in the application of the researcher. The reliability of the study was calculated using the coding reliability formula of Miles and Huberman (1994) (Reliability $=$ Agreements/Agreements + Disagreements) and Cohen's Kappa Statistics. Cohen's Kappa Statistics (Cohen, 1960) was developed to determine the inter-rater reliability of the scoring of the two raters at the classification level, the upper limit was set at 1.00 and the lower limit was -1.00. In the analysis, after the chance factor is removed, the reliability rate can be directly interpreted. In Figure 1, the formula for Kappa analysis is given (Cohen, 1960): 
$p_{o}=$ The Proportion of units in which the judges agreed;

$p_{e}=$ The Proportion of units for which agreement is expected by chance.

Figure 1. The formula for Cohen’s Kappa Analysis (Cohen, 1960)

The reliability values for the comparisons measured with Kappa statistics were evaluated according to the ranges given in Table 1. Kappa Statistic inter-rater reliability value ranges are given in Table 1 (Landis \& Koch, 1977):

Table 1. Kappa Statistic inter-rater reliability value ranges

\begin{tabular}{|l|l|}
\hline Kappa Statistic & Strenght of Agreement \\
\hline$<0.00$ & Poor \\
\hline $0.00-0.20$ & Slight \\
\hline $0.21-0.40$ & Fair \\
\hline $0.41-0.60$ & Moderate \\
\hline $0.61-0.80$ & Substantial \\
\hline $0.81-1.00$ & Almost Perfect \\
\hline
\end{tabular}

Source: Landis and Koch (1977).

Miles and Huberman (2004) stated that the coding reliability should be close to $80 \%$ and a higher level of reliability in such studies. Criterion for the coder reliability level calculated with Miles and Huberman (2004) formula was determined as (Reliability $>.80$ ); values obtained as a result of Kappa Statistics were evaluated according to the ranges suggested by Koch and Landis (1977) in Table 16. Frequency analysis is used to describe the features of the distribution of values or scores related to one or more variables (Büyüköztürk, 2009). The findings obtained at the end of this process are tabulated and expressed in frequency $(f)$ and percentage (\%). Metaphors belonging to the conceptual categories were exemplified by the responses of the participants

\section{Results}

\subsection{Analysis of the Data}

The responses of the students in the semi-structured form, which were asked to determine their perceptions of the environment, were examined and the statements of 329 students who filled the research form in the naming stage as the first stage were listed in alphabetical order. 


\section{Macrothink}

Then, the second stage, sorting (sieving-purification) was started. At this stage, the metaphors they wrote with student expressions were examined under the titles 'subject of metaphor', 'source of metaphor' and 'relationship between source and subject of metaphor', and 90 expressions were eliminated because the metaphor's source-subject and the relationship between the two were incompatible, papers on which 239 expressions remaining after the eliminated statements were written were processed and 45 valid metaphors were obtained from these papers. In the third stage which is the category development stage, these 45 metaphors were reevaluated in terms of their characteristics regarding the concept of environment and 5 different conceptual categories were found. 45 metaphors developed by students are assigned according to their relation to these 5 different conceptual categories. In the fourth stage, the validity and reliability of the research data, coder reliability was performed in order to verify the thematic coding. For this, conceptual categories and 45 metaphors were given to a social studies teacher specialized in their field and asked to classify metaphors according to their relevance under these 5 conceptual categories. The evaluation results of the expert were compared with those of the researcher. In the inter-rater reliability calculation process, the second coder associated 5 metaphors as "Source of Life, Family, Site, Rose, Happiness" with different categories and multiple categories.

\subsection{Reliability and Validity of the Data}

In the comparison made using the formula of Miles and Huberman (1994) (Reliability = Agreements/Agreements + Disagreements); General conceptual coding reliability was found 0.81; Coding reliability in Environment as Living Space category was found .80; Coding reliability in Environment as Polluted-Degraded category was found 0.83; Coding reliability in Environment as Game-Entertainment category was found 1.00; Coding reliability in Environment as Aesthetic-Beauty category was found 0.77; Coding reliability in Environment as Liveliness Expression category has been revealed as 0.77.

The coding reliability was also evaluated with Cohen's Kappa Statistics, accordingly, 'Perfect Fit' was found in Environment as Liveliness Expression category $(\kappa=0.84)$,'Significant Fit' was found in the Environment Category as Living Space $(\kappa=0.75)$,'Perfect Fit' was found in Environment as Polluted-Degraded category $(\kappa=0.89)$, 'Perfect Fit' was found in the Environment as Aesthetics and Beauty category $(\kappa=0.84)$,'Significant Fit' was found in the Environment as Games-Entertainment category $(\kappa=0.79)$. Miles and Huberman $(2004)$ stated that inter-rater reliability should be close to $80 \%$ or more. Therefore, it was revealed that the general conceptual coding reliability and sub-category coding reliability of the qualitative findings had sufficient values.

\subsection{What is The Environment Perception of Fourth Year Primary School Students?}

At the end of this process, which is the fifth stage, the transfer of data to the computer environment was performed. 45 metaphors given under 5 categories were included in the study with percentage and frequency values. Conceptual categories were exemplified by student responses, and the frequency and percentage values of the metaphors in terms of gender, developed by students regarding the concept of environment, are given in Table 2. 
Table 2. Fourth year primary school students regarding the concept of 'Environment'

\begin{tabular}{|c|c|c|c|c|}
\hline \multirow{2}{*}{ Metaphors } & \multicolumn{3}{|c|}{ Metaphors Numbers (f) } & \multirow{2}{*}{ Percentage Rates (\%) } \\
\hline & Male & Female & Total & \\
\hline Life & 17 & 28 & 45 & 18.9 \\
\hline House & 17 & 23 & 40 & 16.8 \\
\hline Heaven & 7 & 14 & 21 & 8.8 \\
\hline Pollution & 10 & 10 & 20 & 8.4 \\
\hline Existence & 6 & 12 & 18 & 7.6 \\
\hline Rubbish & 9 & 8 & 17 & 7.2 \\
\hline Human & 3 & 6 & 9 & 3.8 \\
\hline Home & 1 & 7 & 8 & 3.4 \\
\hline Flower & 3 & 4 & 7 & 2.9 \\
\hline Family & 2 & 2 & 4 & 1.7 \\
\hline Friend & 1 & 3 & 4 & 1.7 \\
\hline Mutual Life Space & - & 3 & 3 & 1.3 \\
\hline Source of Existence & 2 & 1 & 3 & 1.3 \\
\hline Living & 1 & 2 & 3 & 1.3 \\
\hline Natural Beauty & 1 & 2 & 3 & 1.3 \\
\hline Soul & 2 & & 2 & 0.8 \\
\hline Happiness & - & 2 & 2 & 0.8 \\
\hline Natural Life & 2 & - & 2 & 0.8 \\
\hline Bin & 1 & 1 & 2 & 0.8 \\
\hline Fruit & 1 & & 1 & 0.4 \\
\hline Cesspool & - & 1 & 1 & 0.4 \\
\hline Playground & - & 1 & 1 & 0.4 \\
\hline Construction Site & 1 & - & 1 & 0.4 \\
\hline Adult & 1 & - & 1 & 0.4 \\
\hline I & 1 & - & 1 & 0.4 \\
\hline Magic Wand & - & 1 & 1 & 0.4 \\
\hline Paper & - & 1 & 1 & 0.4 \\
\hline Imagination & - & 1 & 1 & 0.4 \\
\hline Amusement Park & - & 1 & 1 & 0.4 \\
\hline Plant & - & 1 & 1 & 0.4 \\
\hline Dream & 1 & - & 1 & 0.4 \\
\hline Heart & - & 1 & 1 & 0.4 \\
\hline
\end{tabular}




\begin{tabular}{|l|l|l|l|l|}
\hline Site & 1 & - & 1 & 0.4 \\
\hline Play & 1 & - & 1 & 0.4 \\
\hline Play Ground & 1 & - & 1 & 0.4 \\
\hline Palace & 1 & - & 1 & 0.4 \\
\hline Resting Place & - & 1 & 1 & 0.4 \\
\hline Football Ground & 1 & - & 1 & 0.4 \\
\hline Peace House & 1 & - & 1 & 0.4 \\
\hline Entertainment & - & 1 & 1 & 0.4 \\
\hline Rainbow & - & 1 & 1 & 0.4 \\
\hline Rose & - & 1 & 1 & 0.4 \\
\hline Mirror & 1 & - & 1 & 0.4 \\
\hline Box & - & 1 & 1 & 0.4 \\
\hline Baby & - & 1 & 1 & 0.4 \\
\hline TOTAL & 97 & 142 & 239 & 100.00 \\
\hline
\end{tabular}

When Table 2 is analyzed, it is seen that primary school students developed 45 metaphors about the concept of environment. When the frequency values of the metaphors was examined, most repeating metaphors were; "Life" $(f=45)$, "Home" $(f=40)$, "Heaven" $(f=$ 21), "Pollution" $(f=20)$, 'Existence' $(f=18)$ and "Rubbish" $(f=17)$ and "Human" $(f=9)$ metaphors. When examined in terms of gender variable, female students mostly developed, respectively, "Life" $(f=28)$, "Home" $(f=23)$, "Heaven" $(f=14)$, 'Existence' $(f=12)$ and "Pollution" ( $f=10)$ metaphors. Male students developed "Life" $(f=17)$, "House" $(f=17)$, "Pollution" $(f=10)$ metaphors. In general, when the numbers of metaphors were examined, female students $(f=142)$ developed more metaphors than male students $(f=97) .45$ valid metaphors developed by primary school students regarding the concept of "Environment" were collected in 5 categories. The findings related to category, metaphor, type and number of metaphors are presented in Table 3. 
Table 3. The Categories, Types, Numbers and Percentage Rates of Metaphors formed by the Fourth Year Primary School Students regarding the concept of 'Environment'

\begin{tabular}{|c|c|c|c|c|c|}
\hline Categories & \multicolumn{2}{|l|}{ Metaphors } & Metaphors & Metaphors & Percentage \\
\hline \multirow{7}{*}{$\begin{array}{l}\text { 'Environment as } \\
\text { Liveliness Expression' }\end{array}$} & Life $(\mathrm{f}=45)$ & Soul $(f=2)$ & \multirow{7}{*}{14} & \multirow{7}{*}{94} & \multirow{7}{*}{39.4} \\
\hline & Existence $(f=18)$ & Heart $(f=1)$ & & & \\
\hline & Human $(f=9)$ & Baby $(f=1)$ & & & \\
\hline & Family $(f=4)$ & Adult $(\mathrm{f}=1)$ & & & \\
\hline & Friend $(f=4)$ & Plant $(f=1)$ & & & \\
\hline & Living $(\mathrm{f}=3)$ & Fruit $(f=1)$ & & & \\
\hline & Source of Existence $(\mathrm{f}=3)$ & $I(f=1)$ & & & \\
\hline \multirow{5}{*}{$\begin{array}{l}\text { 'Environment as } \\
\text { Living Space' }\end{array}$} & House $(\mathrm{f}=40)$ & Palace $(f=1)$ & \multirow{5}{*}{8} & \multirow{5}{*}{57} & \multirow{5}{*}{23.8} \\
\hline & Home $(\mathrm{f}=8)$ & Natural Life $(\mathrm{f}=2)$ & & & \\
\hline & Mutual Life Space $(f=3)$ & $\operatorname{Box}(f=1)$ & & & \\
\hline & Resting Place $(f=1)$ & & & & \\
\hline & Peace House (f:1) & & & & \\
\hline \multirow{5}{*}{$\begin{array}{l}\text { 'Environment as } \\
\text { Polluted-Degraded }\end{array}$} & Pollution (f:20) & Cesspool $(f=1)$ & \multirow{5}{*}{6} & \multirow{5}{*}{42} & \multirow{5}{*}{17.6} \\
\hline & Rubbish $(f=17)$ & & & & \\
\hline & $\operatorname{Bin}(f=2)$ & & & & \\
\hline & Construction Site $(\mathrm{f}=1)$ & & & & \\
\hline & Site $(f=1)$ & & & & \\
\hline \multirow{5}{*}{$\begin{array}{l}\text { 'Environment as } \\
\text { Aesthetic-Beauty' }\end{array}$} & Heaven $(\mathrm{f}=21)$ & $\operatorname{Paper}(\mathrm{f}=1)$ & \multirow{5}{*}{8} & \multirow{5}{*}{36} & \multirow{5}{*}{15.5} \\
\hline & Flower $(\mathrm{f}=7)$ & Dream $(\mathrm{f}=1)$ & & & \\
\hline & Natural Beauty $(\mathrm{f}=3)$ & Rose $(f=1)$ & & & \\
\hline & Mirror $(f=1)$ & & & & \\
\hline & Rainbow $(f=1)$ & & & & \\
\hline \multirow{5}{*}{$\begin{array}{l}\text { 'Environment as } \\
\text { Game-Entertainment' }\end{array}$} & Happiness $(f=2)$ & Entertainment $(f=1)$ & \multirow{5}{*}{9} & \multirow{5}{*}{10} & \multirow{5}{*}{3.7} \\
\hline & Amusement Park $(f=1)$ & İmagination $(f=1)$ & & & \\
\hline & Play $(f=1)$ & Magic Wand $(\mathrm{f}=1)$ & & & \\
\hline & Playground $(\mathrm{f}=1)$ & Play Ground $(\mathrm{f}=1)$ & & & \\
\hline & Football Ground $(\mathrm{f}=1)$ & & & & \\
\hline
\end{tabular}

As can be seen in Table 3, when the metaphors formed by primary school students were categorized in terms of their similarities, 5 conceptual categories were obtained. These categories were defined as 'Environment as Living Space', 'Environment as 
Polluted-Degraded', 'Environment as Game-Entertainment', 'Environment as Aesthetic-Beauty' and 'Environment as Liveliness Expression'.

In the category of 'Environment as Liveliness Expression', which is the first category where students produce the most metaphors, students associated the environment with and life and existence. This category consisted of 14 metaphors as 'Life' $(f=45)$, 'Existence' $(f=18)$, 'Human' $(f=9)$, 'Family' $(f=4)$, 'Friend' $(f=4)$, 'Living' $(f=3)$, 'Source of Existence' $(f=3)$, 'Soul' $(f=2)$, 'Fruit' $(f=1)$, 'Baby' $(f=1)$, 'I' $(f=1)$, 'Plant' $(f=1)$, 'Adult' $(f=1)$, 'Heart' $(f=$ 1) and 94 students $(\% 39,4)$. Below are some of the students' expressions regarding this category:

$23 K$. The environment is like life because the place we live in is the environment. For this reason, we shouldn't throw garbage.

$127 \mathrm{~K}$. The environment is like life because there are flowers, trees, bees and many other useful things in the environment.

$45 K$. The environment is like existence because it is the factor that partially meets all our needs.

153E. The environment is like existence because it is our social life, entertainment and freedom.

$51 K$. The environment is like human because it also lives.

$87 K$ The environment is like friend Because whenever I am alone, I go out, the environment becomes my friend.

$99 K$ The environment is like baby because if we keep it clean, it is clean.

112E. The environment is like my family because as how my parents protect me, I protect my environment.

In the category of 'Environment as Living Space,' which is the second category where students produce the most metaphors, students defined the environment as living space. This category consisted of 8 metaphors as 'House' $(f=40)$, 'Home' $(f=8)$, 'Mutual Life Space' $(f$ $=3)$, 'Box' $(f=1)$, 'Natural Life' $(f=2)$, 'Palace' $(f=1)$, 'Resting Place' $(f=1)$, 'Peace House' $(f=1)$ and 57 students $(23.8 \%)$. Below are sample student statements in this category.

6K. The environment is like mutual life space because all living creatures live together.

156K. The environment is like home because animals nest in places like trees and live there.

$181 \mathrm{~K}$. The environment is like house because it hosts and protects every creature.

$218 K$. The environment is like box because we always wander around.

137K. The environment is like my house because it is like the home of all living and inanimate beings. 
150E. The environment is like peace house because it is quiet and calm as if everyone is asleep.

70E. The environment is like natural life because it is the natural life space of humans and animals.

In the category of 'Environment as Polluted-Degraded' which is the third category where students produce metaphors the most, students defined the environment as polluted and degraded. This category consisted of 6 metaphors as 'Pollution' $(f=20)$, 'Rubbish' $(f=17)$, 'Bin' $(f: 2)$, 'Site' $(f=1)$, 'Construction Site' $(f=1)$, 'Cesspool' $(f=1)$ and 42 students $(17.6 \%)$. Below are some sample student statements in this category.

$175 K$. The environment is like pollution because everyone throws their trash on the floor, not to the bin.

$69 K$. The environment is like rubbish because the environment is so dirty. Because of the smell of the rubbish, some people throw their rubbish as standing behind. The environment is damaged by pollution.

73E. The environment is like rubbish, because they do bad things like smoke coming out of factory chimneys, smoke coming out of car exhausts, polluting the nature of batteries, so it is like garbage.

63E.The environment is like construction site because everywhere has been built, there are buildings everywhere.

129E. The environment is like bin because some people throws their rubbish to the environment, not to the bin.

204E. The environment is like rubbish because nature consciousness is not established in some people. It would be better to open courses in some places.

In the statements of students about environmental perceptions, in the category of 'Environment as Aesthetics and Beauty', students defined the environment as beauty and aesthetics. This category consisted of 9 metaphors as 'Heaven' $(f=21)$, 'Flower' $(f=7)$, 'Natural Beauty' $(f=3)$, 'Rainbow' $(f=1)$, 'Paper' $(f=1)$, 'Rose' $(f=1)$, 'Dream' $(f=1)$, 'Mirror' $(f=1)$ and 36 students $(15.5 \%)$. Below are some sample student statements in this category.

187.K. The environment is like rose because roses are beautiful, the environment is also beautiful, nature is beautiful with greens and flowers. Nature opens itself to us like a peaceful rose.

234.E. The environment is like flower because flowers don't pollute the environment.

101.K.The environment is like heaven because I like forests where there are no houses. Even though I don't see heaven, I think it is a beautiful place because of my belief. I liken places with greenery and trees to heaven.

98.K.The environment is like paper because if we don't use it properly, we lose it. 
114.E.The environment is like dream because I can see all kinds of living things.

75.E. The environment is like natural beauty because the chirping of birds, their sounds, lush vegetation, mountains, meadows are natural beauty.

In the 'Environment as Games and Entertainment' category, where students produce the least metaphors, students defined the environment as games and entertainment. This category consisted of 9 metaphors as 'Happiness' $(f=2)$, 'Magic Wand' $(f=1)$, 'Entertainment' $(f=1)$, 'Amusement Park' $(f=1)$, 'Imagination' $(f=1)$, 'Play' $(f=1)$, 'Playground' $(f=1)$, 'Football Ground' $(f=1)$, 'Play Ground' $(f=1)$ and 10 students $(3.7 \%)$. Below are some sample student statements in this category.

125E. The environment is like playground because I am very excited to play in grassy woods.

$159 K$. The environment is like entertainment because I love the environment, I like to play there and have a picnic.

210K. The environment is like happiness because caring flowers, insects and animals makes me happy.

150E. The environment is like football ground because I love playing ball and everywhere is green.

$108 K$. The environment is like our dreams because only bad people pollute our dreams and also the environment as they don't like it.

97K. The environment is like magic wand because there can be a miracle at any time, suddenly plants grow, animals live in their own cycle.

\section{Discussion and Conclusion}

According to the findings obtained in the research, primary school students produced forty-five different metaphors about the concept of environment and as a result of the conceptual coding, it was found that the primary school students perceive the environment in five different categories as 'Liveliness Expression', 'Living Space', 'Polluted-Degraded', 'Aesthetic and Beauty', 'Play and Entertainment'. The metaphors of the students, which are generally listed under these five categories, are regarded as good world oriented positive metaphors. In the studies of Ertürk (2017), Peker and Ceylan (2016a), and Peker and Ceylan (2016b), primary school students also used positive expressions towards the environment. In this study, when the metaphors that the students produced for the environment were analyzed, it was seen that they mostly used expressions towards the better world. Therefore, students' perceptions of the environment can be included in the classification of the thoughts focused on the good world towards the environment in Alerby's (2000) research.

The number of students answering the question about the concept of environment was 329 . 239 of these students could produce valid metaphors, and the number of metaphors they produced was 45 . The comparison of the number of metaphors produced and the number of students answering the question can be evaluated considering the fact that the students are in the period of concrete operations from the stages of cognitive development, and that, as 
Chauan (2008) also stated, environment has a wide range of things that affect the individual throughout the life. Because the child in this period; have difficulties in understanding and reasoning abstract ideas (McDevitt \& Ormrod, 2002; Woolfolk Hoy, 2004; Slavin, 2013), can process information according to their appearance and physical characteristics, 'objects and settings which they are familiar with', develop concepts, see relationships and solve problems (Vander Zander, 1980; Sprinthall \& Sprinthall, 1990; Woolfolk Hoy, 2004; Slavin, 2013) however they cannot explain the meaning of abstract concepts, even if they use them by modeling adults (Senemoğlu, 2012). Therefore, as Weade and Ernst (1990) suggested that phenomenon they tried to define its metaphors represented not the whole but only a part (as cited in Saban, 2008), and metaphors can be powerful mental tool that work in understanding and explaining a highly abstract, complex or theoretical phenomenon (Saban, 2008), it can be said that the number of metaphors produced by students is sufficient considering that they can perceive only a limited part of the wide concept of the environment and that this situation may be caused by the cognitive period that the students are in. Because, in the research of Çetin (2015), it was revealed that as the age level of the students increased, they were more aware of the environmental events around them. Thus, this situation in the study supported the view of Loughland, Reid, and Petocz's (2002) that children may have a limited or improved understanding of the environment.

When students' metaphors about the concept of environment were examined, they mostly expressed the environment with different metaphors such as 'Life', 'House', 'Heaven', 'Pollution', 'Existence', 'Rubbish', and 'Human'. Therefore, it can be said that students' perceptions of environment vary. The metaphors formed by primary school students regarding the concept of environment showed great similarity with the findings obtained by Doğan (2017) about students' perceptions of the environment and findings of the study by Deniş Çeliker and Akar (2015), and Kahyaoğlu (2015) about students' perceptions of nature. In this research, students expressed the concept of environment more with the metaphor of 'Life'. Similarly, in the study of Deniş Çeliker and Akar (2015), and Doğan (2017), students mostly used the metaphor of 'Life'. It can be said that the students' definition of the environment with the metaphor of life is due to the fact that they attribute the liveliness feature to the environment. Because the environment is a setting in which living processes and liveliness continue, from micro creatures to macro creatures. In this respect, the findings of the study are similar to the findings of the studies by Peker and Ceylan (2016a), Peker and Ceylan (2016b), and Uyanik (2017), which found that students mostly perceived the environment as a living environment.

As a result of the research, most of the students expressed the concept of "Environment" firstly under the category of "Environment as Liveliness Expression" and secondly under the category of "Environment as Living Space". Students perceive the environment as an indicator of liveliness, support of life and ensuring the continuity of life, liveliness and also living space. Similarly, in the study of Kahyaoğlu (2015), students produced metaphors in the category of the vital function of nature. Therefore, this result obtained from the research supported Kahyaoğlu (2015)'s view that student perceive nature as a necessary and important living space for the survival of living things. 
It was revealed that the category of 'Environment as Polluted and Degraded' was the third highest metaphor and frequency number. Under this category, the environment was mostly perceived by students as 'Rubbish' and 'Pollution'. Similarly, in the research of Doğan (2017), it was revealed that the environment was mostly perceived in terms of pollution.

It was found that the fourth highest metaphor and frequency number were gathered under the category of 'Environment as Aesthetics and Beauty'. Similarly, in the study of Köşker (2013), it was found that students defined nature as a source of aesthetics and peace and stated that nature has a relaxing and aesthetic quality. In this category, students perceived the environment as heaven and natural beauty.

It has been revealed that the metaphors of the students were gathered under the category of "Environment as Game and Entertainment", which is the fifth and last. Students see the environment as happiness, play and playground. Köşker (2013) stated that by evaluating the interaction of nature with children in terms of the psychological dimension, planning the activities that they will enjoy in nature towards their interests and curiosity, will affect the perception of nature by children and reinforce their integration with nature.

\subsection{Recommendations}

In the process of teaching environmental issues, it can be said that emphasizing that 'Environment as a Liveliness Expression,' factor of environment supporting the vitality, conducting in-class activities by considering the cognitive period of the students can increase the rate of educational access on environmental issues. It can be concluded that planning and implementing the activities that students will interact with the environment and environmental elements will expand students' perceptions of the concept of environment and also their intellectual perspectives.

\section{References}

Akman, Y., \& Erden M. (2012). Eğitim psikolojisi, gelişim-öğrenme-öğretme. Ankara: Arkadaş Yayınevi.

Alerby, E. (2000). A way of visualising children's and young people's thoughts about the environment: A study of drawings. Environmental Education Research, 6(3), 205-222. https://doi.org/10.1080/13504620050076713

Başal, H. A. (2015). Okul öncesi ve ilkokul öğrencileri için uygulamalı çevre eğitimi. Ankara: Nobel Akademik Yayıncılık.

Büyüköztürk, Ş. (2009). Sosyal bilimler için veri analizi el kitabı: Ístatistik, araştırma deseni SPSS uygulamalarl ve yorum. Ankara: Pegem Akademi.

Büyüköztürk, Ş., Kılıç Çakmak, E., Akgün, Ö. E., Karadeniz, Ş., \& Demirel, F. (2018). Bilimsel araştırma yöntemleri. Ankara: Pegem Akademi Yayıncılık. https://doi.org/10.14527/ 9789944919289

Çetin, G. (2015). Primary school students' views about clean and unclean environment. International Journal of Education, Science and Technology, 1(1), 26-41. 
Chauan, B. S. (2008). Environmental studies. New Delhi: Universitey Science Press. Retrieved from https://books.google.com.tr/books/about/Environmental_Studies.html?id=Pw 6WiYiHPhIC\&redir_esc $=\mathrm{y}$

Cohen, J. (1960). A coefficient of agreement for nominal scales. Educational and Psychological Measurement, 20(1), 37-46. https://doi.org/10.1177/001316446002000104

Demirkaya, H., \& Tomal, N. (2008). Prospective teachers' understandings of Burdur Lake: A Phenomenographic study . Ondokuz Mayls University Journal of Faculty of Education, 25, $1-11$.

Deniş Çeliker, H., \& Akar, A. (2015). Metaphors regarding to nature of middle school students. Journal of Kirsehir Education Faculty, 16(2), 101-119.

Doğan, Y. (2017). Middle school students' intuitive perceptions related to concept of the environment: A metaphor analysis. Ahi Evran Üniversitesi Kırşehir Ĕ̆itim Fakültesi Dergisi (KEFAD), 18(1), 721-740.

Doğru, M., \& Saraç, E. (2013). Metaphors of primary school students relating to the concept of global warming. Educational Research and Reviews, 8(20), 2071-2082. https://doi.org/ 10.5897/ERR11.208

Efron, R. (1969). What is perception? Proceedings of the Boston Colloquium for the Philosophy of Science, 1966-1968 (pp. 137-173). https://doi.org/10.1007/978-94-0103378-7_4

Ertürk, R. (2017). Environmental problems of the primary school students and perceptions for environmental education. Inonu University Journal of the Faculty of Education, 18(3), 12-24. http://doi.org/10.17679/inuefd.354142

Fazio, R. H. (1986). How do attitudes guide behavior. Handbook of motivation and cognition: Foundations of social behavior. New York: Guildford Press.

Hook, P. (2016). The little book of environmental principles. Ankara: Tübitak Yayınları.

İnceoğlu, M. (2011). Tutum, algl, iletişim. Ankara: Siyasal Kitabevi.

Kahyaoğlu, M. (2015). An Investigation of the concept of nature among elementary school students through metaphors analysis. Electronic Turkish Studies, 10(11), 831-845. http://doi.org/10.7827/TurkishStudies.8526

Karasar, N. (2008). Bilimsel araştırma yöntemi. Ankara: Nobel Yayıncılık.

Keklik, N. (1990). Felsefede metafor. İstanbul: İstanbul Üniversitesi Edebiyat Fakültesi Yayını No:358.

Kocataş, A. (2014). Ekoloji ve Çevre Biyolojisi (13rd ed.). Bursa: Dora Yayınc1lık.

Köşker, N. (2013). Primary school students' and prospective primary school teachers' perceptions of nature and toughts of their responsibilities towards the nature. Turkish Studies-International Periodical for the Languages, Literature and History of Turkish or 
Turkic, 8(3), 341-355 http://doi.org/10.7827/TurkishStudies.4037

Landis, J. R., \& Koch, G. G. (1977). The measurement of observer agreement for categorical data. Biometrics, 33, 159-174. https://doi.org/10.2307/2529310

Loughland, T., Reid, A., \& Petocz, P. (2002). Young people's conceptions of environment: A phenomenographic analysis. Environmental Education Research, 8(2), 187-197 https://doi.org/ $10.1080 / 13504620220128248$

McDevitt, T. M., \& Ormrod, J. E. (2002). Child development and education. United States of America: Merril/Prentice Hall.

Miles, M. B., \& Huberman, A. M. (2004). An expanded sourcebook qualitative data analysis, second edition. USA: Sage Production.

Miser, R. (2010). Çevre eğitimi. Ankara: Ankara Üniversitesi Eğitim Bilimleri Fakültesi Mezunları Derneği Yayınları.

Morgan, G (1980). Images of Organization. United States of America: Berret-Koehler Publishers, Inc.

Patton, M. Q. (2014). Nitel analizin kalitesinin ve inanılırlığının artırılması. In S. Çelik \& F. Ö. Karataş (Eds.), Nitel Araştırma ve Değerlendirme Yöntemleri (pp. 541-598). Ankara: Pegem Akademi.

Peker, R., \& Ceylan, S. (2016a). 3th Grade Primary School Student's Conceptions of Environment and Environmental Problems with Solution. In A. İşman \& A. Eskicumalı (Eds.), International Conferance on New Harizons in Education Proceedings Book (Vol. 3, pp. 228-246). Viyana.

Peker, R., \& Ceylan, S. (2016b), İlkokul 3. sını öğrencilerinin çevre ve çevre sorunu algıları ile çözüm önerileri. 3rd İnternational Eurasian Educational Research Congress (EJER)'de sunulmuş bildiri, Muğla Sıtkı Koçman Üniversitesi, Muğla.

Pickens, J. (2005). Attitudes and perceptions. Organizational Behavior of Health Care, 4(7), 43-76.

Power, C., Carmichael, E., \& Goldsmith, R. (2007). Parrot poo on the windscreen: Metaphor in academic skills learning. Journal of Academic Language \& Learning, 1(1), 18-32

Saban, A. (2008). Metaphors about school. Educational Administration: Theory and Practice, 55(5), 459-496.

Sakallı Uğurlu, N. (2018). Sosyal psikolojide tutumlar ve tutum değişimi. Ankara: İmge Kitabevi.

Senemoğlu, N. (2012). Gelişim öğrenme ve öğretim-Kuramdan uygulamaya. Ankara: Pegem Akademi Yayıncılık.

Sever, R., \& Yalçınkaya, E. (2018). Çevre eğitimine genel bir bakış ve temel kavramlar. In R. Sever \& E. Yalçınkaya (Eds.), Çevre Eğitimi (pp. 2-17). Ankara: Pegem Akademi Yayıncılık. 
Slavin, R. E. (2013). Bilgi işlem süreci ve bilişsel öğrenme kuramları. In G. Yüksel (Ed.), Educational psychology theory and practice (pp. 28-47). Ankara: Nobel Akademik Yayıncilik.

Sprinthall, N. A., \& Sprinthall, R. C. (1990). Educational psychology, a developmental approach. New York: McGraw-Hill Inc.

Strenski, E. (1989). Disciplines and communities, 'Armies' and 'Monasteries' and the teaching of composition. Rhetoric Review, 8(1), 137-146. https://doi.org/10.1080/07350198 909388883

Uyanık, G. (2017). Opinions towards environmental pollution of primary school students. Van Yuzuncu Yil University Journal of Education, 14(1), 1574-1600. http://doi.org/10.23891/ efdyyu. 2017.56

Vander Zanden, J. W. (1980). Educational psychology in theory and practice. New York: Random House Inc.

Woolfolk Hoy, A. (2004). Educational psychology. Boston: Allyn and Bacon.

Yob, İ. (1992). Religious metaphor and scientific model: Grounds for comparison. Religious Studies, 28(4), 475-485. https://doi.org/10.1017/S0034412500021879

\section{Copyright Disclaimer}

Copyright for this article is retained by the author(s), with first publication rights granted to the journal.

This is an open-access article distributed under the terms and conditions of the Creative Commons Attribution license (http://creativecommons.org/licenses/by/3.0/). 